Research Article

\title{
Awareness and practice towards dengue fever in Kannamangala village, Bangalore, Karnataka, India
}

\author{
Pradeep C.*, Achuth K. S., Manjula S.
}

Department of Community Medicine, Vydehi Institute of Medical Sciences and Research Centre, India

Received: 17 May 2016

Accepted: 07 June 2016

\author{
*Correspondence: \\ Dr. Pradeep C., \\ E-mail: knightprad@yahoo.co.in
}

Copyright: (c) the author(s), publisher and licensee Medip Academy. This is an open-access article distributed under the terms of the Creative Commons Attribution Non-Commercial License, which permits unrestricted non-commercial use, distribution, and reproduction in any medium, provided the original work is properly cited.

\begin{abstract}
Background: Dengue is a mosquito-borne viral infection of humans. The agent causing dengue is a single-stranded RNA virus of Flaviviridae family. In recent years dengue hemorrhagic fever has become a global public health problem. Urbanization and poor management of garbage in the city limits has resulted in increase in the breeding site for Aedes aegypti which is a vector for dengue fever. The aim and objective was to assess the knowledge, awareness and practices towards dengue fever in Kannamangala village.

Methods: This community based cross sectional study was conducted in Kannamangala village from July 2014December 2014. Totally 738 participants were enrolled in the study. The aim was to assess the knowledge and awareness, preventive measures and most prevalent source of information regarding dengue by using semi-structural questionnaire.

Results: Knowledge and practice regarding dengue fever is not satisfactory, $60 \%$ of the respondents said dengue is a serious illness and $68.8 \%$ said it is transmitted through mosquito bite and only $8 \%$ knew the name of the vector. Only $15.3 \%$ of the participants changed water in artificial container every week, $49.2 \%$ of the respondents got the information from Radio/TV followed by Newspaper/magazine. Only $15.4 \%$ of the respondents received information by Health personnel.

Conclusions: Lack of awareness and improper practice towards dengue is explicit in this study. Emphasis should be more on creating awareness among people. Educational intervention has to be more effective in controlling dengue fever.
\end{abstract}

Keywords: Dengue fever, Knowledge, Awareness, Practices

\section{INTRODUCTION}

Dengue is a mosquito-borne viral disease that has rapidly spread in all regions of WHO in recent years. Female mosquitoes mainly of the species Aedes aegypti and, to a lesser extent, A. albopictus, transmit dengue virus. ${ }^{1}$

Severe dengue (also known as dengue hemorrhagic fever) was first recognized in the 1950s during dengue epidemics in the Philippines and Thailand. Recently dengue is common in Asian and Latin American countries where it has become the leading cause of hospitalization among both adults and children in these regions. ${ }^{1}$

Dengue/dengue hemorrhagic fever (DHF) is an emergent disease in India. The relationship of this country with dengue has been long and intense. The first recorded epidemic of clinically dengue- like illness occurred at Madras in 1780 and the dengue virus was isolated for the first time almost simultaneously in Japan and Calcutta in 1943-1944. After the first virologically proved epidemic of dengue fever along the East Coast of India in 19631964 , it spread to all over the country. The first fullblown epidemic of the severe form of the illness, the 
dengue hemorrhagic fever/ dengue shock syndrome occurred in North India in 1996. It is endemic in 31 states and union territories of the country and contributes annual outbreaks of dengue/ DHF. ${ }^{2-4}$

During 2013 about 74168 cases were reported with 168 deaths, the highest number of cases were reported from Kerala, followed by Odisha, Karnataka, Tamil Nadu and Delhi. ${ }^{5}$ Dengue is been urban disease but has spread to rural areas in recent years due to development activities, water storage practices. ${ }^{6-9}$

Dengue is caused by the infection of dengue virus, a flavivirus in the family of Togaviridae. There are four known virus serotypes (DEN 1, DEN 2, DEN 3, and DEN 4). ${ }^{1,10}$

To tackle increasing dengue cases in urban, peri-urban and rural areas because of expanding urbanization, deficient water and solid waste management, the emphasis is on avoidance of mosquito breeding conditions in homes, workplaces and minimizing the man-mosquito contact. Improved surveillance, case management and community participation, inter-sectoral collaboration, enactment and enforcement of civic bye laws and building bye laws are emphasized for this vector borne disease.

Looking at the cost-effectiveness of the preventive measures over the treatment charges for Dengue fever in private hospitals, there is an urgent need to bring about awareness in people regarding the preventive measures in controlling dengue fever. Thus the present study was taken up to assess the awareness and practice towards the prevention of dengue fever, which serve as an educational diagnosis of a population. This information helps programs set communication objectives linked to increased community engagement and demand for services and develop strategies appropriate for the social, cultural and political contexts of at-risk communities.

\section{METHODS}

The study was conducted in Kannamangala village, which is a field practice area of Vydehi Institute of Medical Sciences \& Research Centre, Bangalore after Ethical clearance from the college.

\section{Sample size and study participants}

A total of 738 houses are in Kannamangala village. Each person from a house was interviewed (738) about the awareness and practice regarding dengue fever.

\section{Interview schedule and data collection}

Pretested semi-structured interview schedule was prepared in Kannada, which is the local language. Questionnaire consisted of four sections. Section I covered demographic information about respondents, section II was about knowledge regarding the symptoms, spread of dengue and also knowledge about mosquitoes. Section III covered about the preventive practices related to dengue and section IV was about source of information about dengue.

A written consent was taken from the participants. People were interviewed in the local language i.e., Kannada. Medico-Social workers conducted interviews from the month of July 2014-December 2014.

\section{Statistical analysis}

Data were entered in Microsoft Excel spreadsheet and analyzed using SPSS version 21.0. The results were recorded as frequencies and $95 \%$ confidence intervals. Chi-square test was used to compare proportions.

\section{RESULTS}

A total of 738 individuals were interviewed. A total of $606(82.1 \%$; 606/738) respondents were females. Mean age of participants was 41.3 years $(\mathrm{SD} \pm 17.41)$. About $16.7 \%$ of the respondents were illiterate and $7.2 \%$ were graduates. $62.5 \%$ of the respondents were housewives. (Table 1).

Table 1: Key socio-demographic profile of the study participants $(n=738)$.

\begin{tabular}{|ll|}
\hline Socio-demographic variables & $\mathbf{N}(\%)$ \\
\hline Gender & \\
\hline Male & $132(17.9)$ \\
\hline Female & $606(82.1)$ \\
\hline Age (years) & $41.3 \pm 17.4$ \\
\hline Education & $123(16.7)$ \\
\hline Illiterate & $174(23.6)$ \\
\hline Primary school & $110(14.9)$ \\
\hline Middle school & $256(34.7)$ \\
\hline High school & $53(7.2)$ \\
\hline Graduate & $22(3.0)$ \\
\hline Degree & \\
\hline Standard of living index & $18(2.4)$ \\
\hline Low & $175(23.7)$ \\
\hline Medium & $545(73.8)$ \\
\hline High &
\end{tabular}

Among 738 subjects 514 (69.6\%) had knowledge about dengue fever and $615(83.3 \%)$ were literates. A significant association was observed between knowledge regarding dengue and education status of the individual (Table 2). Among 738 subjects, 514 (69.6\%) subjects heard about dengue and $439(59.5 \%)$ of the respondents said Dengue is a serious illness. $293(39.7 \%)$ respondents said they are at risk of getting Dengue.

Overall $508(68.8 \%)$ subjects said it is transmitted through mosquito bite and only $63(8.5 \%)$ knew the name 
of the vector. Around $84(11.4 \%)$ said the mosquito is a day biter and $305(41.4 \%)$ said it bites in both day and night. $213(28.9 \%)$ of the respondents said it breeds in pots, cans and water container, $423(57.3 \%)$ said in ponds and river.

Table 2: Knowledge regarding dengue fever according to education.

\begin{tabular}{|llll|}
\hline $\begin{array}{l}\text { Literacy } \\
\text { status of } \\
\text { subjects }\end{array}$ & $\begin{array}{l}\text { Knowledge regarding } \\
\text { dengue fever }\end{array}$ & Total \\
\cline { 2 - 3 } & $\begin{array}{l}\text { Yes } \\
\text { Number } \\
(\%)\end{array}$ & $\begin{array}{l}\text { Number } \\
(\%)\end{array}$ & $\begin{array}{l}\text { Number } \\
(\%)\end{array}$ \\
\hline Illiterate & $45(36.6)$ & $78(63.4)$ & $123(16.6)$ \\
\hline $\begin{array}{l}\text { Primary- } \\
\text { high school }\end{array}$ & $420(77.8)$ & $120(22.2)$ & $540(73.2)$ \\
\hline $\begin{array}{l}\text { Diploma- } \\
\text { degree }\end{array}$ & $49(69.4)$ & $26(30.6)$ & $75(10.2)$ \\
\hline Total & $514(69.6)$ & $224(30.4)$ & $738(100)$ \\
\hline
\end{tabular}

$\chi^{2}=81.2, \mathrm{DF}=2, \mathrm{P}=0.001$.

The major sources of information regarding dengue were television/radio 363 (49.2\%), health personnel 114 (15.4\%), newspaper/magazine $173(23.4 \%)$ and from past illness of dengue $67(9.1 \%)$ (Table 3$)$.

Table 3: Source of information regarding dengue fever.

\begin{tabular}{|ll|}
\hline Source of information & Number (Percentage) \\
\hline Television / radio & $363(49.2 \%)$ \\
\hline Newspaper/ magazine & $173(23.4 \%)$ \\
\hline Health personnel & $114(15.4 \%)$ \\
\hline Relatives/ friends & $104(14.1 \%)$ \\
\hline Past illness of dengue & $67(9.1 \%)$ \\
\hline *Multiple responses $(\mathrm{n}=738)$. &
\end{tabular}

$459(62.2 \%)$ out of 738 subjects knew that dengue could be prevented. A significant association was observed between the knowledge regarding prevention of dengue and education status of the subjects (Table 4).

Table 4: Knowledge regarding prevention of dengue fever to education.

\begin{tabular}{|llll|}
\hline \multirow{4}{*}{$\begin{array}{l}\text { Literacy } \\
\text { status of } \\
\text { Subjects }\end{array}$} & \multicolumn{2}{l}{$\begin{array}{l}\text { Knowledge regarding } \\
\text { prevention dengue fever }\end{array}$} & Total \\
\cline { 2 - 3 } & $\begin{array}{l}\text { Yes } \\
\text { Number } \\
(\boldsymbol{\%})\end{array}$ & $\begin{array}{l}\text { No } \\
(\boldsymbol{\%})\end{array}$ & $\begin{array}{l}\text { Number } \\
(\boldsymbol{\%})\end{array}$ \\
\hline Illiterate & $62(50.4)$ & $61(49.6)$ & $123(16.6)$ \\
\hline $\begin{array}{l}\text { Primary-high } \\
\text { school }\end{array}$ & $340(63.0)$ & $200(37.0)$ & $540(73.2)$ \\
\hline $\begin{array}{l}\text { Diploma- } \\
\text { degree }\end{array}$ & $57(76)$ & $18(24)$ & $75(10.2)$ \\
\hline Total & $459(62.2)$ & $279(37.8)$ & $738(100)$ \\
\hline$\chi^{2}=13.5, \mathrm{DF}=2, \mathrm{P}=0.001$. & & \\
\hline
\end{tabular}

Common preventive practices used in the community were using mosquito repellents 407 (55.14\%), mosquito nets $158(21.4 \%)$, removal of standing water 128 $(17.34 \%)$.

Out of 738 subjects $712(96.5 \%)$ of the respondents said they covered the storage container when not in use. When it comes to changing of water $333(45.2 \%)$ said they do it daily, $101(13.7 \%)$ on alternate days and $113(15.3 \%)$ once a week (Table 5).

Table 5: Distribution of respondents as per their practices of mosquito control.

\begin{tabular}{|ll|}
\hline Method of prevention* & Number (\%) \\
\hline Mosquito repellents & $407(55.14 \%)$ \\
\hline Mosquito nets & $158(21.4 \%)$ \\
\hline Removal of standing water & $128(17.34 \%)$ \\
\hline Changing of water in container & \\
\hline Daily & $333(45.2 \%)$ \\
\hline Alternate days & $101(13.7 \%)$ \\
\hline Once a week & $113(15.3 \%)$ \\
\hline
\end{tabular}

*Multiple responses $(\mathrm{n}=738)$

\section{DISCUSSION}

The present study was able to document the knowledge and practices regarding the dengue. In present study the mean age of subjects was 41.3 years ( $\mathrm{SD} \pm 17.4$ years) and $123(16.7 \%)$ were illiterates. In similar study by Chinnakali et al mean age of participants was 33.8 years and about $14 \%$ of the respondents were illiterates. ${ }^{11}$

In present study out of 738 subjects 514 (69.6\%) had heard about dengue disease and 459 (62.2\%) knew it could be prevented, though $30.4 \%$ did not have knowledge. However, Kumar et al in Tamil Nadu in which only $34.5 \%$ of the public was aware of dengue fever. $^{12}$

In present study significant association was found between literacy status and knowledge regarding dengue fever and its prevention. In similar study by Acharya et al $90 \%$ respondents were aware of dengue and a statistical significance was found between literacy status and knowledge about dengue fever. ${ }^{13}$

Regarding source of information $49.2 \%$ respondents cited the media, $23.4 \%$ respondents cited newspaper. A similar study by Taksande $\mathrm{A}$ et al and Matta $\mathrm{S}$ et al reported higher observation for media $59.7 \%$ and $57 \%$ respectively. ${ }^{14,15}$

In present study, 55\% of the subjects used mosquito repellent as the major mosquito preventive measure. In a similar study by Naik PR et al mosquito repellent use was $46.57 \%$ and in a study by Matta $\mathrm{S}$ et al $77 \%$ used mosquito repellent. ${ }^{15,16}$ 


\section{CONCLUSION}

This study clearly shows, there is lack of awareness among the people about the dengue preventive measures. Focus should be more on educating people about the preventive measures through health workers and mass media. Behaviour change communication sessions has to be conducted regularly in rural areas regarding mosquito control measures.

\section{ACKNOWLEDGEMENTS}

Authors would like to thank the department of Community Medicine, Vydehi Institute of Medical Sciences and Research centre, for supporting me in doing this work. I also thank my colleagues for their valuable inputs. And my sincere thanks to all Kannamangala village residents who participated in this study and without whom the study wouldn't have been possible.

\section{Funding: No funding sources}

Conflict of interest: None declared

Ethical approval: The study was approved by the Institutional Ethics Committee

\section{REFERENCES}

1. World Health Organization. Dengue and severe dengue. Fact Sheet No. 117, February 2015; WHO, Geneva.

2. Sharma SN, Raina VK, Kumar A. Dengue/DHF: an emerging disease in India. $\mathbf{J}$ Commun Dis. 2000;32(3):175-9.

3. Chaturvedi UC, Nagar R. Dengue and dengue hemorrhagic fever: Indian perspective. J Biosci. 2008;33(4):429-41.

4. Park K. Park's Textbook of Preventive and Social Medicine. 23rd ed. Jabalpur: Banarasidas Bhanot Publishers; 2015.

5. Govt. of India (2015). National Health Profile 2015, DGHS, Ministry of Health and Family Welfare, New Delhi.

6. Mehendale SM, Risbud AR, Rao JA, Banerjee K. Outbreak of dengue fever in rural areas of Parbhani district of Maharashtra (India). Indian J Med Res. 1991;93:6-11.
7. Arunachalam N, Murty US, Kabilan L, Balasubramanian A, Thenmozhi V, Narahari D, Ravi A, Satyanarayana K. Studies on dengue in rural areas of Kurnool District, Andhra Pradesh, India. J Am Mosq Control Assoc. 2004;20(1):87-90.

8. Paramasivan R, Dhananjeyan KJ, Leo SV, et al. Dengue fever caused by dengue virus serotype-3 (subtype-III) in a rural area of Madurai district, Tamil Nadu. Indian J Med Res. 2010;132:339-42.

9. Hati AK. Studies on dengue and dengue haemorrhagic fever (DHF) in West Bengal State, India. J Commun Dis. 2006;38(2):124-9.

10. Maxcy-Roseneau-Last. Public health and preventive medicine.Mc Graw Hill pub. 2008;15:350-51.

11. Chinnakali P, Gurnani N, Upadhyay RP, Parmar K, Suri TM, Yadav K. High level of awareness but poor practices regarding dengue fever control: A cross-sectional study from North India. North Am J Med Sci. 2012;4(6):278-82.

12. Kumar AV, Rajendran R, Manavalan R, Tewari SC, Arunachalam N, Ayanar K,Krishnamoorthi R, Tyagi BK. Studies on community knowledge and behavior following a dengue epidemic in Chennai city, Tamil Nadu, India. Tropical Biomedicine. 2010;27(2):3306.

13. Acharya A, Goswami K, Srinath S, Goswami A. Awareness about dengue syndrome and related preventive practices amongst residents of an urban resettlement colony of south Delhi. J Vect Borne Dis. 2005;42:122-7.

14. Taksande A, Lakhkar B. Knowledge, Attitude and Practice (KAP) od Dengue Fever in the Rural Area of Central India. Shiraz E-Medical Journal. 2012;13:146-57.

15. Matta S, Bhalla S, Singh D, Rasania SK, Singh S. Knowledge, Attitude and Practice (KAP) on Dengue fever: A Hospital Based Study. Indian Journal of Community Medicine. 2006;31:185-6.

16. Naik PR, Nirgude AS, Prakash KG.Knowledge and preventive practices regarding dengue among adult population of rural area of Nalgonda district, South India. Int J Biol Med Res. 2011;2(3):652-5.

Cite this article as: Pradeep C, Achuth KS, Manjula $\mathrm{S}$. Awareness and practice towards dengue fever in Kannamangala village, Bangalore, Karnataka, India. Int J Community Med Public Health 2016;3:1847-50. 